American Journal of Environmental Sciences 6 (5): 438-441, 2010

ISSN 1553-345X

(C) 2010 Science Publications

\title{
Comparison of Selected Soil Chemical Properties of Two Different Mangrove Forests in Sarawak
}

\author{
${ }^{1}$ Empi Rambok, ${ }^{1}$ Seca Gandaseca, \\ ${ }^{2}$ Osumanu Haruna Ahmed and ${ }^{1}$ Nik Muhamad Ab. Majid \\ ${ }^{1}$ Department of Forestry Science, \\ ${ }^{2}$ Department of Crop Science, \\ Faculty of Agriculture and Food Sciences, \\ University Putra Malaysia, Bintulu Sarawak Campus, \\ 97008 Bintulu, Sarawak, Malaysia
}

\begin{abstract}
Problem statement: Despite few studies of forest health and environmental conditions of mangrove forest in Sarawak, the data was not sufficient to facilitate baseline data and direct comparison of mangrove forest health obtained for different location of mangrove forest in Sarawak. On this regard, determination of contemporary mangrove soil condition was essential to addressing mangrove forest for forest health, carbon storage and environmental balance. The study attempts to obtained preliminary database of mangrove forest soil chemical properties and to compare the forest health from two different mangrove forest locations. Approach: Mangrove soil samples were taken from Miri and Limbang Division of Sarawak at 0-30 cm depth. Selected soil chemical properties were determined and data obtained were analyzed using Statistical Analysis System (SAS) Version 9.2. Results: The soil acidity, total N, total P, CEC and humic acid of both locations were significantly different while in terms of total carbon and organic matter were similar. Conclusion: Regional diversity has significant effects the soil acidity, total N, total P, CEC and yield of the study areas. Data obtained can be useful for further study of carbon stock and nutrient content
\end{abstract}

Key words: Mangrove forest, soil chemical properties, regional diversity, Total Carbon (TC), Cation Exchange Capacity (CEC), Statistical Analysis System (SAS), Total Nitrogen (TN)

\section{INTRODUCTION}

Mangrove forests are one of the most productive ecosystems, growing on sheltered shores and in estuaries in the tropics and can be found in some subtropical area (Hogarth, 1999). Mangrove forests are high in values, multiple roles and important for human and microbes continuity. Sarawak-Malaysia has about (172,792 ha) of mangrove forest which are found along coastline regions (Bennett and Reynolds, 1993). Mangrove forests in Sarawak values consist of both goods and services benefit such as forestry industry, fisheries industry, wildlife conservation, tourist industry and protection of the physical environment (Bennett and Reynolds, 1993; Lai et al., 1993).

Soil properties of mangrove forest such as soil chemical properties can indicate the current status and determined the characteristics of tested soil. Data obtained may represent the soil fertility thus to plan a proper action for enhancement of soil quality and governing ideal ecosystem. As medium of growth, soil should supplies enough nutrients and have good characteristic to ensure better tree performance and establish greater forest ecosystem for wildlife conservation, economic value and most important to balancing environmental condition. The objective of this study was to compare selected soil chemical properties of two different mangrove forests.

\section{MATERIALS AND METHODS}

The study was conducted at Wildlife Sanctuary Sibuti Mangrove Forest, Miri (WSSM) and Awat-Awat Lawas Mangrove Forest, Limbang (AALL) in the State of Sarawak, Malaysia. Soil sampling was done in December 2009 and January 2010 respectively. Forty soil samples were taken at $0-30 \mathrm{~cm}$ depth in a 0.5 hectare plot using peat auger. The samples were air-

Corresponding Author: Seca Gandaseca, Department of Forestry Science, Faculty of Agriculture and Food Sciences, University Putra Malaysia, Bintulu Sarawak Campus, 97008 Bintulu, Sarawak, Malaysia 
dried, grinded and sieve to pass a $0.2 \mathrm{~mm}$ sieve. Soil $\mathrm{pH}$ was determined based on the method of Tan (2005). Soil Organic Matter (OM) and Total Carbon (TC) were analyzed using the loss in ignition method as represented by Fiala and Krhovjakova (2008). Leaching method by Cottenie (1980) and Berg and Gardner (1978) were used to determine soil Cation Exchange Capacity (CEC). Total Nitrogen (TN) was determined by using the Kjeldahl method (Jones, 2001) and Total Phosphorus (TP) was determined using Aqua Regia and the Blue Method of Bray and Kurtz (1945) and Salimin et al. (2010). Humic acid was determined accordingly to method of Kasim et al. (2008). Statistical Analysis System (SAS) Version 9.2 and t-test were used for statistical analysis to test the significances of soil chemical properties between two locations.

\section{RESULTS}

Figure 1-7 indicate the means comparison of selected soil chemical properties between WSSM and AALL.

Soil at AALL was more acidic and showed significant difference both in water and $\mathrm{KCl}$ (Fig. 1).

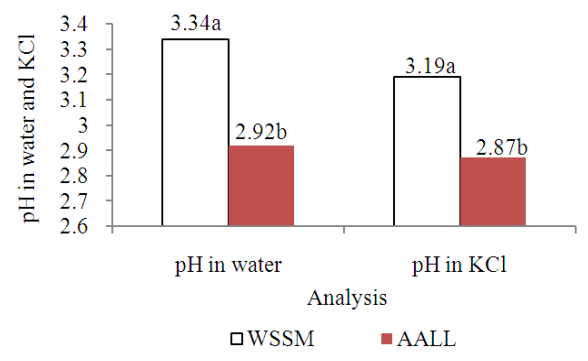

Fig. 1:Comparison of soil acidity in water and with $\mathrm{KCl}$ of two different mangrove forests. Mean followed by different letter at the top was significantly difference using t-test at $\mathrm{p} \leq 0.05$

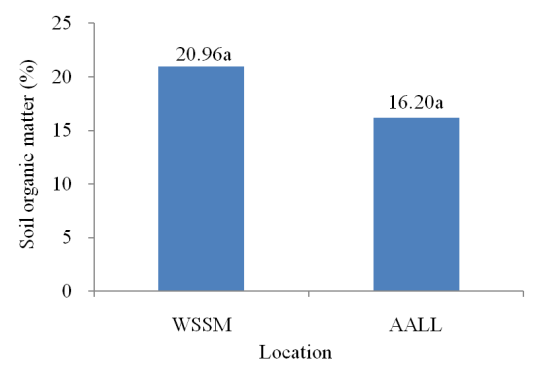

Fig. 2: Comparison of soil organic matter (\%) of two different mangrove forests. Mean followed by different letter at the top was significantly difference using t-test at $\mathrm{p} \leq 0.05$
The organic matter and total carbon of the two locations were statistically different (Fig. 2 and 3). However, the opposite was true for total N, total P, CEC and yield of both location (Fig. 1 and 4-7).

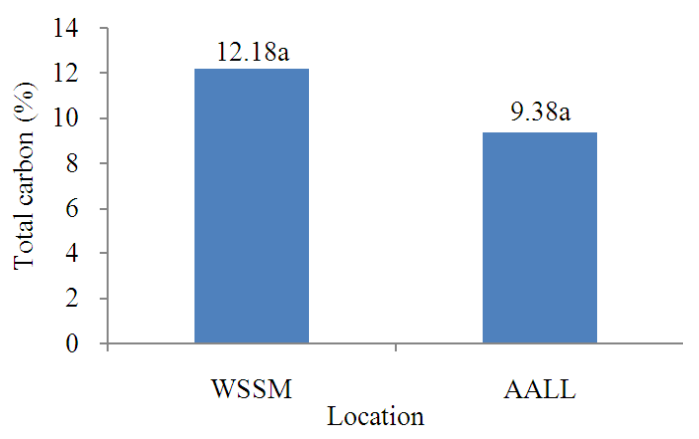

Fig. 3: Comparison of total carbon (\%) of two different mangrove forests. Mean followed by different letter at the top was significantly difference using t-test at $\mathrm{p} \leq 0.05$

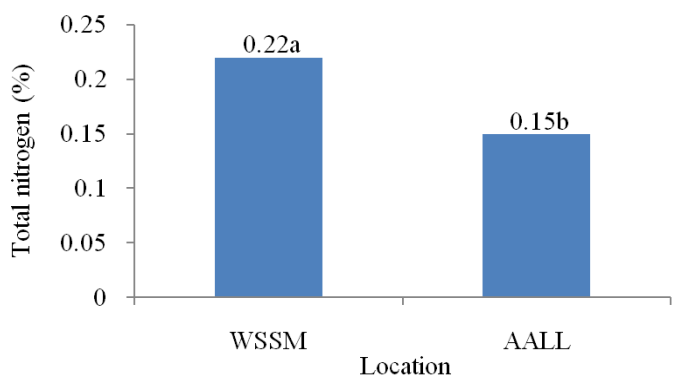

Fig. 4:Comparison of total nitrogen (\%) of two different mangrove forests. Mean followed by different letter at the top was significantly difference using t-test at $p \leq 0.05$

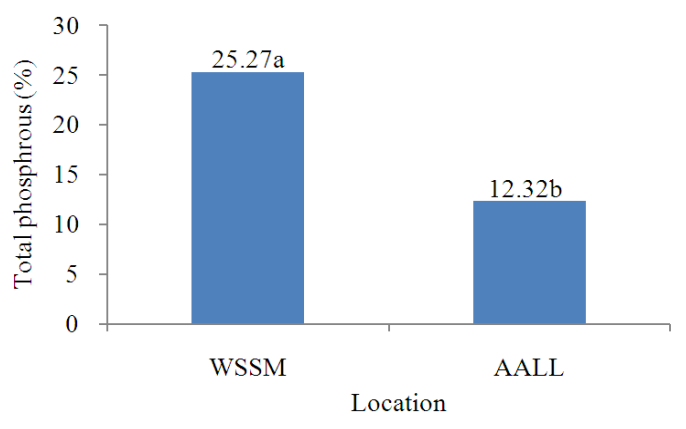

Fig. 5:Comparison of total phosphorus (\%) of two different mangrove forests. Mean followed by different letter at the top was significantly difference using t-test at $p \leq 0.05$ 


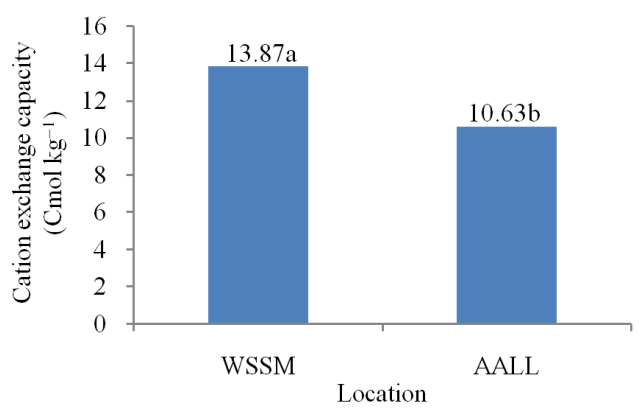

Fig. 6: Comparison of cation exchange capacity $(\mathrm{cmol}$ $\mathrm{kg}^{-1}$ ) of two different mangrove forests. Mean followed by different letter at the top was significantly difference using $\mathrm{t}$-test at $\mathrm{p} \leq 0.05$

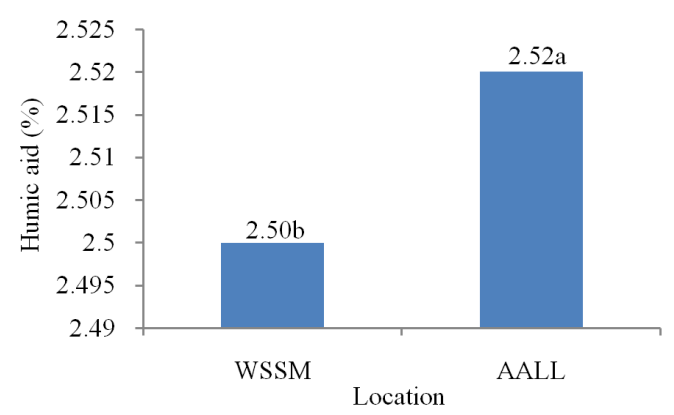

Fig. 7:Comparison of humic acid (\%) of two different mangrove forests. Mean followed by different letter at the top was significantly difference using t-test at $\mathrm{p} \leq 0.05$

\section{DISCUSSION}

Soil at AALL plot found to be more acidic than at WSSM area. AALL is situated at the shore edge thus the soil is easily and frequently soaked with sea water. The soil at WSSM is less acidic compared to AALL because the forest is situated in Sibuti River which is rarely and indirectly flooded with sea water. Soil acidity in mangrove forest is related to humic acid, cation exchange capacity and amount of carbonic acid, iron and manganese hydroxides and carbonates store in soil at particular period (Boto and Wellington, 1984).

Percentage of OM and total $\mathrm{C}$ in soil at both sites were not significantly different. Organic matter and carbon content including humus in soil at mangrove forest are decomposed from fall trees biomass (leaves, twig, branches and other part), microorganism, material and sludge from flooded water. Higher OM contents in soils are contributed by litter fall of Rhizophora apiculata covered at the plot study. Soils of mangrove forest are easily prone to soft rate of silting which makes the soil more darkness in color resulting high organic matter contents in soil (Akram et al., 2009). Amount of total $\mathrm{C}$ found in soil is related to content of organic matter occupied in soil (Hasrizal et al., 2009; Anton et al., 2009).

AALL mangrove forest had the lower CEC compared to soil at WSSM mangrove forest and this was because of the lower $\mathrm{pH}$ of AALL compared with WSSM. The situation was because the concentrations of hydrohen sulphide accumulated in soil (Sukardjo, 1994). Cation exchange capacity sustain chemical properties as well as soil fertility, by causing and correcting soil acidity and basicity, in altering soil physical properties and in purifying percolation water.

Total $\mathrm{P}$ and total $\mathrm{N}$ in Fig. 4 and 5 showed there were significant different between two study area. Amount of nitrogen available in soil is correlated to anaerobic condition and nitrate bacteria. Soil at WSSM mangrove forest was had higher value of total $\mathrm{N}$ and total $\mathrm{P}$ compared to AALL mangrove forest. Nitrite or nitrate form from nitrification process occurs at root zone that released oxygen. The concentration of dissolved inorganic nitrogen and inorganic phosphorus is generally low in mangrove forest due to infrequently anaerobic condition (Alongi, 1996). Relationship between soil acidity and amount of humic acid can be represented when more acidic soil of AALL mangrove forest resulting the significances of humic acid value compared to WSSM mangrove forest. Amount of humic acid obtained contents of stable and unstable carbon which is essential to determine carbon stock in soil.

\section{CONCLUSION}

Location affects soil acidity, total N, total P, CEC and yield of humic acid as they were different for AALL and WSSM.

\section{ACKNOWLEDGEMENT}

We thank University Putra Malaysia for funding this research. We also thank Sarawak Forestry Department, Miri Forestry Department and Department of Forestry Science for their cooperation.

\section{REFERENCES}

Akram, A., A. Alfarhan, E. Robinson and W. Altesan, 2009. Soil quality of die off and die back mangrove grown at al-Jubail area (Saudi Arabia) of the Arabian Gulf. Am. J. Applied Sci., 6: 498-506. http://www.scipub.org/fulltext/ajas/ajas63498506.pdf 
Alongi, D.M., 1996. The dynamics of benthic nutrient pools and fluxes in tropical mangrove forests. J. Marine Res., 54: 123-148. DOI: 10.1357/0022240963213475

Anton, E.S., S. Gandaseca, O.H. Ahmed and N.M.A. Majid, 2009. Influence of chemical properties on soil carbon storage of a tropical peat swamp forest. Am. J. Applied Sci., 6: 1969-1972. DOI: 10.3844/ajassp.2009.1969.1972

Berg, M.G. and E.H. Gardner, 1978. Methods of soil analysis used in the soil testing laboratory at Oregon State University. The Valley Library. http://ir.library.oregonstate.edu/xmlui/handle/1957/ 4418

Bennett, E.L. and C.J. Reynolds, 1993. The value of a mangrove area in Sarawak. Biodiver. Conserv., 2: 359-375. DOI: 10.1007/BF00114040

Boto, K.V. and J.T. Wellington, 1984. Soil characteristics and nutrient status in a Northern Australian mangrove forest. Estuaries Coasts, 7: 61-69. DOI: 10.2307/1351957

Bray, R.H. and L.T. Kurtz, 1945. Determination of total, organic and available forms of phosphorus in soils. Soil Sci., 59: 39-46.

Cottenie, A., 1980. Soil and Plant Testing as a Basis of Fertilizer Recommendation. 1st Edn., Food and Agriculture Organization of the United Nations, Rome, ISBN: 10: 9251009562, pp: 100.

Fiala, K. and J. Krhovjakova, 2008. Application of lossof-ignition method to the soil organic carbon determination. Geophys. Res. Abstr., 10: 1-2.

Hasrizal, S., B.Y. Kamaruzzaman, I. Sakri, M.C. Ong and M.S.N. Azhar, 2009. Seasonal distribution of organic carbon in the surface sediments of the Terengganu Nearshore coastal area. Am. J. Environ. Sci., 5: 111-115. DOI: 10.3844/ajessp.2009.111.115
Hogarth, P.J., 1999. The Biology of Mangroves. 1st Edn., Oxford University Press, United Sates, ISBN: 0198502230, pp: 228.

Jones, Jr., J.B., 2001. Laboratory Guide for Conducting Soil Tests and Plant Analysis. 1st Edn., CRC Press, USA, ISBN: 0849302064, pp: 384.

Kasim, S., O.H. Ahmed, N.M.A. Majid and M.K. Yusop, 2008. Simple method of purifying humic acids isolated from tropical hemists (Peat Soil). Am. J. Applied Sci., 5: 1812-1815. DOI: 10.3844/ajassp.2008.1812.1815

Lai, H.C., H.J. Teas, F. Pannier and J.M. Baker, 1993. Biological impact of oil pollution: Mangrove. International Petroleum Industry Environmental Conservation Association (IPIEACA).

Salimin, M.I., S. Gandaseca, O.H. Ahmed and N.M.A. Majid, 2010. Comparison of selected chemical properties of peat swamp soil before and after timber harvesting. Am. J. Environ. Sci., 6: 164-167. DOI: 10.3844/ajessp.2010.164.167

Sukardjo, S., 1994. Soils in the mangrove forest of the Apar Nature Reserve, Tanah Grogot, East Kalimantan, Indonesia. Southeast Asian Stud., 32: 385-398. http://ci.nii.ac.jp/naid/110000200650

Tan, K.H., 2005. Soil Sampling Preparation and Analysis. 2nd Edn., Taylor and Francis, New York, ISBN: 0849334993, pp: 623. 